\title{
Helminth infection in Mugil incilis from Cartagena de Indias, Colombian Caribbean coast
}

\author{
L. IGLESIAS, R. BENÍTEZ, F. J. ADROHER*, A. VALERO
}

\begin{abstract}
Departamento de Parasitología, Facultad de Farmacia, Universidad de Granada, Campus Universitario de Cartuja, E-18071 Granada, España,*E-mail:fadroher@ugr.es
\end{abstract}

\begin{abstract}
Summary
This survey records the occurrence of larvae of Contracaecum multipapillatum sensu lato (Von Drasche, 1882) Lucker, 1941 (Nematoda, Anisakidae) and adults of Floridosentis mugilis (Machado Filho, 1951) Ward, 1953 (Acanthocephala, Neoechinorhynchidae) in mullet Mugil incilis Hancock, 1830 caught in La Boquilla, Cartagena de Indias (Colombian Caribbean coast). The prevalence of $F$. mugilis was $45.7 \%$ and of C. multipapillatum s.l. $58.6 \%$, while $28.6 \%$ of the fish were parasitized by both species. The smallest hosts presented the lowest prevalence of $F$. mugilis but the highest prevalence of $C$. multipapillatum s.l. Prevalence, mean abundance and mean intensity of $C$. multipapillatum s. $l$. in $M$. incilis were all highest in viscera. The prevalence in fish muscle tissue was low $(2.9 \%)$.

Keywords: fish; Mugil incilis; Floridosentis mugilis; Contracaecum multipapillatum sensu lato; Colombia; Acanthocephala; Anisakidae
\end{abstract}

\section{Introduction}

Several authors have described the presence of anisakid nematode larvae of the genus Contracaecum Railliet and Henry, 1912 and the acanthocephalan Floridosentis mugilis (Machado Filho, 1951) Ward, 1953 in mullet caught on the coast of the American continent. Bravo-Hollis (1969) found the acanthocephalan $F$. elongatus Ward, 1953 (=F. mugilis) and F. pacifica in striped mullet (Mugil cephalus) in the Mexican Pacific. Also, from this host on the same coast, Salgado-Maldonado and Barquín-Álvarez (1978) and Iglesias et al. (1998) isolated larvae of Contracaecum sp. and adults of F. elongatus, and Valles-Ríos et al. (2000) only found C. multipapillatum (Von Drasche, 1882) Lucker, 1941 larvae. Also, larvae of Contracaecum sp. were found in striped mullet from Peruvian (Armas, 1979; Pérez et al., 1999) and Chilean (Fernández-Bargiela, 1987) waters. In a study carried out by Galiano and Romero
(1979) on parasites of M. curema Valenciennes, 1836 from the Ciénaga Grande de Santa Marta (Colombia), larvae of Contracaecum sp. were described in the muscle and many of the fish's organs. Later, Deardorff and Overstreet (1980) found third stage larvae (L3) of C. multipapillatum in $M$. cephalus from the Gulf of Mexico, and studied the infectivity of these in various animals. Juárez-Arroyo and Salgado-Maldonado (1989) described in detail the larvae of Contracaecum sp. in $M$. cephalus which came from the port of Topolobambo (Sinaloa, Mexico), and the morphological characteristics they found agree with those described by Salgado-Maldonado and Barquín-Álvarez (1978).

This study examines the occurrence of larvae of C. multipapillatum sensu lato and adults of $F$. mugilis in the mullet M. incilis Hancock, 1830 from La Boquilla, Cartagena de Indias (northern Colombia).

\section{Materials and methods}

A total of 70 specimens of Mugil incilis (mullet) originating from the area of La Boquilla and acquired on ice from a popular fish market in Cartagena de Indias (Colombia) were studied. The length of the fish ranged between 20 and $33 \mathrm{~cm}$, and their height between 4 and $6 \mathrm{~cm}$. Immediately after purchase they were dissected in the laboratory and their viscera and muscle carefully examined for nematodes and acanthocephalans. The parasites obtained were deposited in saline solution for later identification. The parasites collected were fixed in hot $70^{\circ}$ alcohol, cleared in lactophenol and stained with a few drops of cotton blue, for two days for acanthocephalans and 7 days for nematodes, prior to morphological identification based on the descriptions of Bullock (1962), Bravo-Hollis (1969), Salgado-Maldonado and Barquin-Álvarez (1978), and Juárez-Arroyo and Salgado-Maldonado (1989) for Floridosentis mugilis and Huizinga (1967) and Deardorff and Overstreet (1980) for 
Contracaecum multipapillatum sensu lato. No molecular identification was carried out. The association between fish length and parasite prevalence was analyzed using Fisher's exact test to compare prevalences and a bootstrap 2-sample t-test to compare mean intensities and abundances, with $95 \%$ confidence intervals being determined when possible. These analyses were performed using free "Quantitative Parasitology 3.0" software developed by Reiczigel and Rózsa in 2005, Budapest (theoretical background in Rózsa et al. 2000).

\section{Results}

Of the 70 mullet analyzed, $24.3 \%$ were males, $41.4 \%$ females and the rest immature. The average length \pm standard deviation of males was $27.7 \pm 1.6 \mathrm{~cm}$, of females 28.3 $\pm 2.1 \mathrm{~cm}$, and of juveniles $23.8 \pm 2.2 \mathrm{~cm}$. The overall average length was $26.5 \pm 2.8 \mathrm{~cm}$. The number of specimens infected was $53(75.7 \%)$, of which $32(45.7 \%)$ contained acanthocephalans, 41 (58.6\%) contained nematode larvae, and $20(28.6 \%)$ harbored both parasites. A total of 288 parasites were collected: 168 acanthocephalans and 120 nematodes. The acanthocephalans were juveniles or adults of Floridosentis mugilis, and were only found in the intestine, preferably in the lumen of the beginning of the second half of the intestinal tract. The parasites were yellowish white in colour, with little movement and were quite fragile. Following the criteria of Bush et al. (1997), the prevalence found for this parasite was $45.7 \%$, its mean abundance (A) 2.40, mean intensity (I) 5.25, with a range of 1 to 22 .

The 120 nematodes studied were isolated from the viscera and muscle. Some parasites, especially in the liver, had formed oval-shaped capsules in which they were coiled in a spiral. When removed from the capsules, they exhibited slow movements and a reddish white colouring. The viscera with the highest parasite burdens were liver and kidney. A burden of up to 7 individuals in the kidney was observed in one fish. All anisakids were in L3 and were identified as Contracaecum multipapillatum sensu lato. The total prevalence of C. multipapillatum s.l. was $58.6 \%$, A was $1.73, \mathrm{I}=2.95$ with a range of 1 to 9 . The muscle was least affected (Table 1).

Table 1. Prevalence (P), mean abundance (A) and mean intensity (I) of $C$. multipapillatum in M. incilis according to location

\begin{tabular}{|c|c|c|c|c|c|}
\hline & $\mathrm{N}^{\mathrm{a}}$ & $\mathrm{n}^{\mathrm{b}}$ & $\begin{array}{c}\mathrm{P} \\
95 \% \mathrm{CI}^{\mathrm{c}}\end{array}$ & $\begin{array}{c}\mathrm{A} \\
95 \% \mathrm{CI}\end{array}$ & $\begin{array}{l}\text { I (range) } \\
95 \% \text { CI }\end{array}$ \\
\hline Viscera & 41 & 118 & $\begin{array}{c}58.6 \\
46.4-69.8\end{array}$ & $\begin{array}{c}1.69 \\
1.26-2.20\end{array}$ & $\begin{array}{l}2.88(1-9) \\
2.37-3.54\end{array}$ \\
\hline Muscle & 2 & 2 & $\begin{array}{c}2.9^{*} \\
0.5-9.8\end{array}$ & $\begin{array}{c}0.03 * \\
0.00-0.07\end{array}$ & $\begin{array}{c}1.00 *(1-1) \\
\mathrm{d}\end{array}$ \\
\hline
\end{tabular}

Statistical comparison: $* \mathrm{p}<0.001$

${ }^{\mathrm{a} N u m b e r}$ of parasitized hosts

${ }^{\mathrm{b}} \mathrm{Number}$ of parasites

${ }^{\mathrm{c}} 95 \%$ confidence interval

${ }^{\mathrm{d}} 95 \%$ confidence intervals are uncertain
The prevalence, A and I of C. multipapillatum s.l. and $F$. mugilis in relation to the host's size and sex are shown in Tables 2 and 3 . The smallest hosts $(20-24 \mathrm{~cm})$ presented the lowest prevalence of $F$. mugilis, but the highest prevalence of C. multipapillatum s.l..

\section{Discussion}

We are not aware of any research on Mugil incilis from La Boquilla in Cartagena de Indias (Colombia) which studies the acanthocephalan Floridosentis mugilis and the nematode Contracaecum multipapillatum sensu lato. Galiano and Romero (1979), in their study carried out in Ciénaga de Santa Marta (Colombia), identified larvae of Contracaecum and several specimens of acanthocephalans (specific identification was not carried out) in the host $M$. curema.

The morphological characteristics of the two parasitic species studied here are similar to those described by Salgado-Maldonado and Barquín-Álvarez (1978) and Iglesias et al. (1998) in M. cephalus. Also, Deardorff and Overstreet (1980) studied the larvae of Contracaecum found in the liver and kidney of $M$. cephalus originating in the Gulf of Mexico, identifying them as $C$. multipapillatum. They suggested that the larval stages found by Salgado-Maldonado and Barquín-Álvarez (1978) were also C. multipapillatum larvae. However, Juárez-Arroyo and Salgado-Maldonado (1989) consider that they should be denominated Contracaecum sp., adducing the wide geographical distribution of Mugilidae and the geographical amplitude in which larval forms of this nematode have been located. This is due largely to the migratory habits of the ichtyophagous birds - one of their definitive hosts - and, above all, to the great polymorphism presented by the larvae, which could indicate the occurrence of several species of Contracaecum in the same host and geographical area (Juárez-Arroyo \& Salgado-Maldonado, 1989). Using molecular tools, it has recently been shown that $C$. multipapillatum is a complex comprising several species with distinct geographical distributions (Mattiucci et al., 2006; D’Amelio et al., 2007; Mattiucci et al., 2010; Shamsi et al., 2011).

The prevalence of $F$. mugilis was $45.7 \%$, with up to 22 parasites in the intestine of a single host, while intestinal obstructions and even perforations could be observed. This prevalence is lesser than reported by Salgado-Maldonado and Barquín-Álvarez (1978) and Iglesias et al. (1998) in the intestine of $M$. cephalus from the Gulf of Mexico and the Mexican Pacific Ocean, who found a maximum intensity of 33 and 60 acanthocephalans, respectively.

The total prevalence and I obtained for the larvae of $C$. multipapillatum s.l. were $58.6 \%$ and 2.95 respectively, lower than those found by Galiano and Romero (1979), which were $77.5 \%$ and 6.8 respectively, although it should be noted that the mullet species and the habitats were different. The larvae of C. multipapillatum s.l. were found not only in viscera, but also in the muscle (Table 1).

As the size (age) of the fish increased, so did the preva- 
Table 2. Prevalence (P), mean abundance (A) and mean intensity (I) of C. multipapillatum and F. mugilis according to host length (M. incilis)

\begin{tabular}{|c|c|c|c|c|c|}
\hline Parasite/Fish length ${ }^{\mathrm{a}}$ & $\mathrm{N}^{\mathrm{b}}$ & $n^{c}$ & $\begin{array}{c}\mathrm{P} \\
95 \% \mathrm{CI}^{\mathrm{d}} \\
\end{array}$ & $\begin{array}{c}\mathrm{A} \\
95 \% \mathrm{CI} \\
\end{array}$ & $\begin{array}{l}\text { I (range) } \\
95 \% \mathrm{CI}\end{array}$ \\
\hline \multicolumn{6}{|l|}{ C. multipapillatum } \\
\hline $20-24 \mathrm{~cm}$ & 17 & 29 & $\begin{array}{c}64.7 \\
40.6-83.4\end{array}$ & $\begin{array}{c}1.76 \\
0.94-3.18\end{array}$ & $\begin{array}{c}2.73(1-9) \\
1.73-4.73\end{array}$ \\
\hline $25-28 \mathrm{~cm}$ & 34 & 68 & $\begin{array}{c}55.9 \\
38.1-72.4\end{array}$ & $\begin{array}{c}1.94 \\
1.26-2.71\end{array}$ & $\begin{array}{l}3.47(1-7) \\
2.74-4.32\end{array}$ \\
\hline $29-33 \mathrm{~cm}$ & 19 & 23 & $\begin{array}{c}52.6 \\
31.2-74.3 \\
\end{array}$ & $\begin{array}{c}1.21 \\
0.58-1.89 \\
\end{array}$ & $\begin{array}{c}2.30(1-4) \\
1.50-2.90\end{array}$ \\
\hline \multicolumn{6}{|l|}{ F. mugilis } \\
\hline $20-24 \mathrm{~cm}$ & 17 & 26 & $\begin{array}{c}35.3 \\
16.6-59.4\end{array}$ & $\begin{array}{c}1.53 \\
0.53-2.76\end{array}$ & $\begin{array}{c}4.33(1-7) \\
3.00-5.00\end{array}$ \\
\hline $25-28 \mathrm{~cm}$ & 34 & 92 & $\begin{array}{c}44.1 \\
27.6-61.9\end{array}$ & $\begin{array}{c}2.71 \\
1.29-5.26\end{array}$ & $\begin{array}{l}6.17(1-22) \\
3.47-10.93\end{array}$ \\
\hline $29-33 \mathrm{~cm}$ & 19 & 50 & $\begin{array}{c}57.9 \\
34.5-77.8\end{array}$ & $\begin{array}{c}2.63 \\
1.26-4.42\end{array}$ & $\begin{array}{c}4.55(1-11) \\
2.82-6.91\end{array}$ \\
\hline
\end{tabular}

\footnotetext{
${ }^{\mathrm{a}}$ Statistical comparison of the da
${ }^{\mathrm{b}}$ Number of hosts examined.
${ }^{\mathrm{c}}$ Number of parasites collected.

${ }^{\mathrm{d}} 95 \%$ confidence intervals
}

lence of F. mugilis (possible accumulative effect with age), whilst for C. multipapillatum s.l., it diminished (Table 2), perhaps due to the mullet changing diet with age. The epidemiological parameters determined for mullet parasitation by $C$. multipapillatum s.l. and F. mugilis show no differences between male and female mullet (Table 3 ). other hand, Galiano and Romero (1979) pointed out the frequent presence of Contracaecum larvae in the muscle of M. curema. Furthermore, Vidal-Martínez et al. (1994) argued that $C$. multipapillatum larvae may mature and penetrate the alimentary canal of humans. However, the low prevalence of anisakids recorded in fish muscle

Table 3. Relationship between sex of the host (M. incilis) and prevalence (P), mean abundance (A) and mean intensity (I) of parasitization by C. multipapillatum and F. mugilis

\begin{tabular}{|c|c|c|c|c|c|}
\hline Parasite/Host sex ${ }^{a}$ & $\mathrm{~N}^{\mathrm{b}}$ & $\mathrm{n}^{\mathrm{c}}$ & $\begin{array}{c}\mathrm{P} \\
\mathrm{CI}^{\mathrm{d}}\end{array}$ & $\begin{array}{l}\text { A } \\
\text { CI }\end{array}$ & $\begin{array}{l}\text { I (range) } \\
\text { CI }\end{array}$ \\
\hline \multicolumn{6}{|l|}{ C. multipapillatum } \\
\hline Males & 17 & 20 & $\begin{array}{c}41.2 \\
19.6-65.0\end{array}$ & $\begin{array}{c}1.06 \\
0.47-1.76\end{array}$ & $\begin{array}{c}2.57(1-4) \\
1.71-3.29\end{array}$ \\
\hline Females & 29 & 43 & $\begin{array}{c}55.2 \\
35.7-72.8 \\
\end{array}$ & $\begin{array}{c}1.52 \\
0.93-2.24\end{array}$ & $\begin{array}{l}2.75(1-7) \\
2.06-3.50\end{array}$ \\
\hline \multicolumn{6}{|l|}{ F. mugilis } \\
\hline Males & 17 & 37 & $\begin{array}{c}41.2 \\
19.6-65.0\end{array}$ & $\begin{array}{c}2.18 \\
1.00-4.18\end{array}$ & $\begin{array}{c}5.29(1-11) \\
3.43-7.86\end{array}$ \\
\hline Females & 29 & 103 & $\begin{array}{c}62.1 \\
43.0-77.9\end{array}$ & $\begin{array}{c}3.52 \\
1.83-6.14\end{array}$ & $\begin{array}{c}5.67(1-22) \\
3.33-9.11\end{array}$ \\
\hline
\end{tabular}

Finally, the L3 of Contracaecum have a special significance because of their implication in human anisakidosis (Williams \& Jones, 1976; Smith \& Wootten, 1978). However, this aspect has been questioned due to the low rate of infestation of larvae in the fish musculature (Huang, 1988; Angot \& Brasseur, 1995), although Schaum and Müller (1967) described a case of a human with C. osculatum. Iglesias et al. (1998) found C. multipapillatum s.l. prevalence in the muscle of $5.5 \%$ in $M$. cephalus compared to $2.9 \%$ in $M$. incilis (Table 1) in the present study. On the strongly indicate that the risk of contracting anisakidosis, from consumption of raw or semi-cooked mullet captured from La Boquilla in northern Colombia (SW Caribbean Sea), is very small, if at all.

\section{Acknowledgements}

We are very grateful to Dr Jorge Mercado-Silgado (Instituto Nacional de Pesca y Acuicultura, Ministerio de Agricultura, Cartagena de Indias, Colombia) for the identifica- 
tion of the host species and Dr Robin M. Overstreet (Gulf Coast Research Laboratory, Institute of Marine Sciences, University of Southern Mississippi, Ocean Springs, MS, USA) for the specific morphological identification of Contracaecum, as well as their comments on the draft version of this manuscript. This work has been possible thanks to a Programa Intercampus fellowship awarded to Luis Iglesias by the Spanish Government. The manuscript was translated into English by Mrs Gillian Butcher and the corrected version was revised by $\mathrm{Mr}$ Robert Abrahams, B.Sc.. All the surveys described comply with current Spanish laws.

\section{References}

Angot, V., Brasseur, P. (1995): Les larves d'Anisakides et leur incidence sur la qualité des poissons et produits de poisson. Rev. Méd. Vét., 146: $791-804$

ARMAS, G. (1979): Observations on diseases and parasites of mullet alevins Mugil cephalus L. from the Río Moche coastal lagoon of Peru. J. Fish Dis., 2: 543 - 547

BuLlOCK, W. L. (1962): The status of the acanthocephalan genera Floridosentis Ward, 1953 and Atactorhynchus Chandler, 1935. Proc. Helminthol. Soc. Washington, 29: $217-218$

Bravo-Hollis, M. (1969): Helmintos de peces del Pacífico Mexicano. XXVIII. Sobre dos especies del género Floridosentis Ward, Neoechinorhynchidae Van Cleave, 1919. An. Inst. Biol. Univ. Nal. Autón. México, Ser. Zool., 40: $1-14$

Bush, A. O., Lafferty, K. D., Lotz, J. M., Shostak, A. W. (1997): Parasitology meets ecology on its own terms: Margolis et al. revisited. J. Parasitol., 83: 575 - 583.

D’Amelio, S., BArros, N. B., Ingrosso, S., FAuQuier, D. A., Russo, R., PAGgi, L. (2007): Genetic characterization of members of the genus Contracaecum (Nematoda: Anisakidae) from fish-eating birds from west-central Florida, USA, with evidence of new species. Parasitology, 134: 1041 - 1051. DOI: 10.1017/S003118200700251X

DeArdorfF, T. L., OverstreEt, R. M. (1980): Contracaecum multipapillatum $(=C$. robustum) from fishes and birds in the Northern Gulf of Mexico. J. Parasitol., 66: 853 - 856 FERNÁNDEZ-BARGIELA, J. (1987): Los parásitos de la lisa Mugil cephalus L., en Chile: Sistemática y aspectos poblacionales (Perciformes: Mugilidae). Gayana, Zool., 51: 3 - 58

Galiano, M., Romero, M. (1979): Parásitos de peces de la Ciénaga de Santa Marta. Tesis de Grado en Biología, Colombia, Bogotá: Departamento de Biología, Facultad de Ciencias, Universidad Nacional de Colombia.

HuANG, W. (1988): Anisakidés et anisakidoses humaines. Deuxième partie: Enquête sur les Anisakidés de poissons comerciaux du marché parisien. Ann. Parasitol. Hum. Comp., 63: $197-208$

HuizingA, H. W. (1967): The life cycle of Contracaecum multipatillatum (von Drasche, 1882) Lucker, 1941 (Nematoda: Heterocheilidae). J. Parasitol., 53: 368 - 375 Iglesias, L., Gómez Del Prado, M. C., Adroher, F. J.,
VALERO, A. (1998): Floridosentis mugilis y Contracaecum sp., parásitos de Mugil cephalus en Baja California Sur, México. I Virtual Congress on Pharmacy, Granada, Spain. JuÁreZ-Arroyo, J., SAlgado-MALdONADO, G. (1989): Helmintos de la "lisa" Mugil cephalus Lin. en Topolobambo, Sinaloa, México. An. Inst. Biol. Univ. Nal. Autón. México, Ser. Zool., 60: 279 - 295

Mattiucci, S., Paoletti, M., Olivero-Verbel, J., ARroyo, B., BALDiris, R., NASCETTI, G. (2006). Evidence for new species of Contracaecum Railliet et Henry, 1912 (Nematoda, Anisakidae), parasites of fish-eating birds from Colombia: genetic relationships between congeners, and larval identification. Parassitologia, 48: 351

Mattiucci, S., Paoletti, M., Solorzano, A. C., NAscetti, G. (2010): Contracaecum gibsoni n. sp. and $C$. overstreeti n. sp. (Nematoda: Anisakidae) from the Dalmatian pelican Pelecanus crispus (L.) in Greek waters: genetic and morphological evidence. Syst. Parasitol., 75: 207 - 224. DOI: 10.1007/s11230-009-9220-8

Nascetti, G., Cianchi, R., Mattiucci, S., D'amelio, S., Orecchia, P., Paggi, L., Brattey, J., Berland, B., Smith, J. W., Bullini, L. (1993): Three sibling species within Contracaecum osculatum (Nematoda, Ascaridida, Ascaridoidea) from the Atlantic Arctic-Boreal region: reproductive isolation and host preferences. Int. J. Parasitol., 23: $105-120$

Orecchia, P., Mattiucci, S., D'amelio, S., Paggi, L., Plötz, J., Cianchi, R., NAscetti, G., Arduino, P., Bullini, L. (1994): Two new members in the Contracaecum osculatum complex (Nematoda, Ascaridoidea) from the Antarctic. Int. J. Parasitol., 24: $367-377$

PÉrez, I., ChÁvez, A., CASAs, E. (1999): Presencia de formas parasitarias en peces comerciales del mar peruano. Rev. Inv. Vet. Perú, 10: $34-38$

Reiczigel, J., RózSA, L. (2005): Quantitative Parasitology, Version 3.0 [computer software]. Budapest. Distributed by the authors (http://www.zoologia.hu/qp/qp.html).

RózSA, L., REICZIGEL, J. MAJOROS, G. (2000): Quantifying parasites in samples of hosts. J. Parasitol., 86: 228 - 232. DOI: 10.1645/0022-3395(2000)086[0228:QPISOH]2.0.CO;2 SAlgado-Maldonado, G., BARQuín-ÁlvareZ, N. P. (1978): Floridosentis elongatus Ward, 1953 y Contracaecum sp. parásitos de Mugil cephalus Linnaeus, 1758. An. Inst. Biol. Univ. Nal. Autón. México, Ser. Zool., 49: 71 - 82 SchAuM, E., MÜLLER, W. (1967): Die Heterocheilidiasis. Eine Infektion des Menschen mit Larven von Fish-Ascariden. Dtsch. Med. Wochenschr., 92: 2230 - 2233

SHAMSI, S., GASSER, R., BEVERIDGE, I. (2011): Mutation scanning-coupled sequencing of nuclear ribosomal DNA spacers as a tool for the specific identification of different Contracaecum (Nematoda: Anisakidae) larval types. Mol. Cell. Probes, 25: 13 - 18. DOI: 10.1016/j.mcp.2010.09.003

Smith, J. W., Wootten, R. (1978): Anisakis and anisakiasis. Adv. Parasitol., 16: 93 - 163

VAlles-Ríos, M. E., Ruiz-CAMPos, G., Galavíz-Silva, L. (2000): Prevalencia e intensidad parasitaria en Mugil cephalus (Pisces: Mugilidae), del río Colorado, Baja Cali- 
fornia, México. Rev. Biol. Trop., 48: 495 - 501

VidAl-Martínez, V. M., OSORIO-SARABIA, D., OverSTREET, R. M. (1994): Experimental infection of Contracaecum multipapillatum (Nematoda: Anisakinae) from

RECEIVED JANUARY 25, 2010
Mexico in the domestic cat. J. Parasitol., 80: 576 - 579 WiLliams, H. H., JONES, A. (1976): Marine helminths and human health. CIH Miscellaneous Publ., No. 3. Farnham Royal, Bucks, England, C. A. B., 47 p.

ACCEPTED NOVEMBER 16, 2010 